\title{
A Study of the Fostering Function of University Personal File on Campus Culture
}

\author{
Qianbai Shi \\ Huaihua University, Huaihua, 418000, China
}

Keywords: University personal file; Campus culture, Fostering function

\begin{abstract}
University personal file is the important component of the school cultural construction, the concrete records of the school development, the concentration of the school history and culture and the representation of the prominent figures in the school. Therefore, it plays a very significant role in promoting the comprehensive qualities of the students. In the university construction, school should pay abundant attention to the role of university human archives in the construction of the campus culture, which not only fully develops the role of university personal file in the training of the university students' comprehensive qualities, but also allows full play to the existence value of university personal file. This text conducts a detailed discussion from three aspects which are the overview of university personal file, the fostering function of the university personal file on campus culture and its construction measures by taking the university personal file as research objects and based on construction of campus culture.
\end{abstract}

\section{Introduction}

Mei Yiqi, a famous educator, once said that 'what makes a good university is the amount and quality of masters it owns instead of the amount and quality of buildings that stands.' He thinks that university should be the birthplace of the important idea in the society, the place of master gathering and the place for the spread of advanced ideas. And university personal file is the concrete records of the masters in the campus and the records of the life history and remarkable contributions of the masters reflect the masters' noble morality and advanced ideas. Therefore, it is a live textbook for the current university students. Through the investigation of the credibility of the university personal file, the author finds that about $97 \%$ of the students choose to believe the records of university personal file and they think that these records highly restore the history. It fully shows that the students' acceptability of university personal file is very high. Therefore, it lays a solid foundation for the university personal file to develop its role in the campus culture construction.

\section{The Overview of the University Personal File}

The so-called university personal file means the various forms of historical records of words, charts, and sound images formed by the prominent figures when they engage in the activities such as politics, economics and culture. ${ }^{[1]}$ For the university personal file, the file objects are mainly the knowledgeable experts, the young scholars with significant contributions and the classic campus figures. University personal file, which conducts the real records of the different stages of the school development and the research activities in different fields, becomes a mirror of the university campus culture which reflects the essence of the university campus culture.

Generally, university personal file owns the characteristics in the following aspects: firstly, university personal file owns authenticity. University personal file is the real records of the various activities in the university and high restoration of the circumstance at that time, so it possesses originality. Secondly, university personal file is educational. What the university personal file records is the self-development of the university which mainly includes the development history and achievements, thus it reflects the activities in different aspects at different periods of the university development and is the main resource to educate the students in aspects of thought and culture. Thirdly, university personal figure is knowledgeable. University is the important place for the 
students to accept higher education and students acquire knowledge and inherit culture in the university. Therefore, university mainly takes cultivating the knowledgeable, civilized and moral personnel as its educational goal while university personal file is an important carrier to record the knowledge and culture in the university. Fourthly, university personal file is cultural. University is the important place for the human culture transmission and development and usually the advanced idea of a country is born and improving constantly in the university. University personal file inherits these thoughts through the records of these prominent figures so as to make the university culture pass on from one generation to generation ${ }^{\text {[2] }}$. Fifthly, university personal file is social. University personal file which is the records of the practical activities of the prominent figures not only spreads widely inside the campus, but also influences the development of the whole society. Therefore, it becomes an organic component of the social culture

\section{The Fostering Function of the University Personal File on Campus Culture}

Campus culture is made up of students and teachers together and it is the concentrated reflection of the ideology, value orientation and thinking mode of the students and teachers in the university. University personal file is the fountain of campus culture and has significant influence on the campus culture.

\section{Humanistic Education Effect of the University Personal File}

University personal file is the records of the long history of the school and it includes the excellent revolutionary cultural resources, prominent people cultural resources and the construction achievements of the school. It is the sedimentary deposit of humanistic spirit of the students and teachers of each generation and contains abundant humanistic connotation. Therefore, it is most effective textbook to conduct humanistic education toward the students. In university education, applying university personal file into the campus culture construction not only mirrors the profound historical and cultural connotation of the university, but also reflects the humanistic spirit of the university historic culture, which has unintended educational effects on the university students.

\section{The Spiritual Education Effect of the University Personal File}

University personal file is the records of the figures who have made outstanding contribution for the university and the records of their social activities at different periods. Therefore, their fine spirits are planted and concentrated here at the university. It is mainly manifested in the following aspects: first of all, as to their noble spirit, university personal file records their tough and struggling course, manifests their spirit of advocating science, purchasing the truth and exploring and innovating; secondly, as to their excellent personality, university personal fils demonstrates their character of instructing others indefatigably and rigorous scholarship; lastly, as to their value orientation, university personal file manifests their life pursuit which is being contented in poverty and taking plight in teaching, seeking no fame or gains and devoting to education ${ }^{\text {[31 }}$. Therefore, these noble characters can motivate the university students to combine their life value with the social demand organically and link their long-sighted dream with the foothold actuality, which not only helps the university students set up the correct three reflections, but also fully improves their comprehensive quality.

\section{Example Education Effect of the University Personal File}

University students have strong desire to realize their own value, but their value, outlook on life and world outlook are not fully formed. Therefore, they are still confused about the direction of life they should choose. However, university personal file, which records the growth process of the outstanding people, reveals their struggling experience under the hard conditions while examples are very important to the university students ${ }^{[3]}$. Conducting the positive example education toward the university students by applying university personal file and making the prominent figures become the objects for the university students to follow help them set their own struggling objectives and provide good direction for them to realize their goals. Thus it's guaranteed that they can move forward on the right path. 


\section{Environmental Education Effect of University Personal Files}

At present, in the campus of various universities, we can see the 'object achieves' including the statues, pictures and quotations of the prominent figures which not only demonstrate the philosophy of schooling and school-running characteristics, but also inherit the school' humanistic spirits. They have become an indispensable part of the campus cultural construction. The material objects such as the statues and pictures in the campus construction pass on the school's thought, specification and value standard to the students and teachers symbolically. Therefore, these abstract objects have potential effect on the personality shaping and cultivating of the students invisibly.

\section{Measures for Strengthening the Fostering Function of the University Personal File on Campus Culture}

\section{Developing and Utilizing University Personal File Vigorously}

University can make the efforts from the following aspects: firstly, university archives departments should develop the personal file resources vigorously. They should carry out the editing research of the personal file actively at work and utilize the archives holdings in the school so as to construct the mission archives showroom or the school history museum for the school. These places should be made as the important bases for the spiritual education of the university students ${ }^{\text {[4] }}$. Secondly, schools can launch some special events such as special events of the famous teachers, special events of the school history and the special events of the famous alumni, etc by utilizing the historical data of the personal files in the school so as to amplify the influence of the personal file data on the teachers and students. Thirdly, school can raise some funds to shoot the personal files of the school into the telefilm or edit them into the picture album and then make these materials as the teaching aids for the students to study. Therefore, university students fully perceive their campus life, understand their school and are integrate into the campus cultural construction actively.

\section{Strengthening the Application of University Personal File in the Class}

Since university personal file usually owns the characteristics of authenticity, vitality and proximity, so school can make the university personal file as the teaching materials and edit them into a book. Then school can set up specialized courses for the students, so that the university personal file data can be an effective means for the students to study ideology and politics and edify the mind and body of the students. Therefore, it not only makes the students strengthen their understanding about prominent figures and school history in the mandatory study, but also makes the correct ideology of the prominent figures pierce the hearts of the students imperceptibly. From the perspective of the teachers, they should conduct the classroom teaching in the form of story in the teaching process of prominent figures and school history. Such live and vivid teaching method not only improves the students' interest in learning prominent figures and school history, but also makes the classroom teaching more lively and infectiously ${ }^{\mathbf{5} \mathbf{1}}$.

Strengthening the Application of University Personal File in Faith Education of the Students

School can organize the students to look for some information about some school prominent figures in the archives room or school history museum at proper time. When students are learning the information, they can absorb the useful academic ideas and outstanding achievements of the prominent figures at different historical periods. In the meanwhile, the precious qualities on these prominent figures will perceive into the heart of the students in an invisible way and leave a mark on their hearts to edify their emotions. Therefore, students can be influenced deeply in the real and genuine atmosphere. The profound influence helps the students gradually set the correct ideal and faith which directs their life with correct value. This spiritual influence gradually turns into the daily behavior of the students and directs their life with the correct belief so as to open up a broader life path.

\section{Strengthening the School History Education by Utilizing University Personal File.}

University personal file is the carrier of school history and culture and bears the changes of the school. Therefore, for the university, if they want to make every student who enters the university proud of their own school, then they should make the students have strong understanding of their 
school and the history. Only in this way can the students build close relationship with their schools and have strong feelings toward their school ${ }^{\mathbf{6} 6 \mathbf{1}}$. School should take advantage of every picture, every file in the university personal file, conduct organic combination of these contents and present them to the students in live and vivid images. Historical culture of the school nourishes the students and students are enlightened from it. Through specific practices, we find that for the university students, the enlightenment gained from the school history or the spirit of the prominent figures perceive into their mind more than the stuffs learned in traditional classroom.

\section{Strengthening the Campus Culture by Utilizing University Personal Files}

Various universities can build the corresponding campus human landscape such as the statue of prominent figures or the corridor of prominent alumni by taking the university personal files as the important resources and blend the unique human spirit of the school into every tree and every bush in the school to present the unique humanistic charm of the school. As the students are in a new historical period, they have new interpretation toward the human landscape from their own perspective and establish the overall relationship with the human landscape under gradual understanding. In the organic relationship, they gain the spiritual education with lofty sentiments and the silent nourishment gradually cultivates the students who feel the edification of humanistic spirit in their living environment. Therefore, students are influenced invisibly and they keep improving their spiritual state and set up the spirit of learning from the prominent figures.

\section{Conclusion}

To sum up, campus culture is the concentration of school culture, the spiritual heritages of the long development of the school, the inheritance of the school excellent culture and the organic components of the advanced socialist culture. University personal file, which is an important part of the campus culture, has the effect on the following four aspects during the education process of the students: humanistic education effect, spiritual education effect, example education effect and environmental education effect. Aiming at the measures for the fostering function of the university personal file on campus culture, school can make efforts from the following five aspects: developing and utilizing the university personal file vigorously, strengthening the application of university personal file in the class, strengthening the application of university personal file in faith education of the students, strengthening the school history education by utilizing university personal file and strengthening the campus culture by utilizing university personal file. Only in this way can the fine campus cultural environment be built, can the comprehensive quality of the students be improved and can the students be urged to establish correct outlook on life, value and world outlook and move forward on the right direction.

\section{References}

[1] Zhangyao. Fully Developing the Function of University Archives and Promoting the Realization of Fostering Function. Lantai World, 2013.

[2] Wu Huihong, Xujie. University Archives and Campus Cultural Construction. Heilongjiang Historical Annals, 2008.

[3] Gaopeng. On the Cultural Cultivation Function of University Archives, Intelligence, 2013.

[4] Wu Xuejun. Developing the Role of University Archives in Campus Cultural Construction. Archives and Construction, 2003.

[5] Gao Yongqing. Consideration for the Broadening of the Working Fields of University Archives by Relying on School History Exhibition.Beijing Archive, 2012.

[6] Chen Weidong. Strengthening University Archives and Constructing Harmonious Campus-On the Effect of the Participation of University Archives in Campus Culture Construction. Archives of Electromechanical Warship, 2006. 